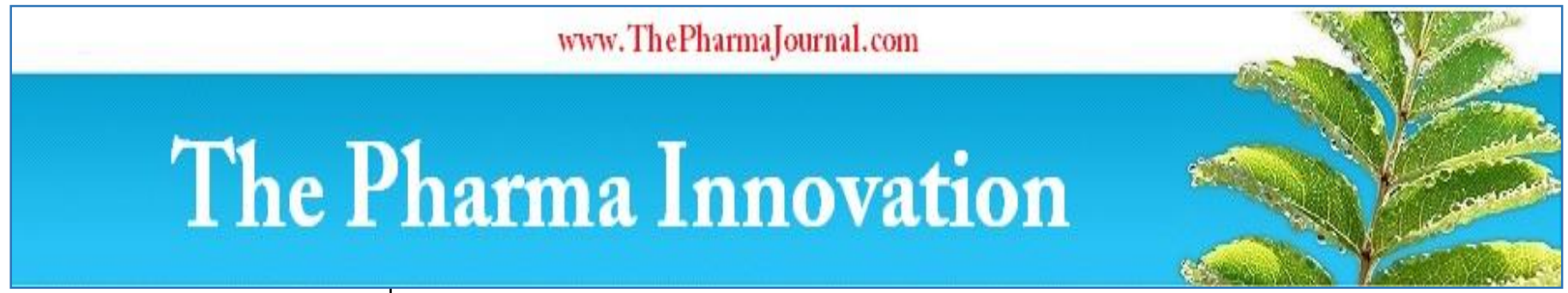

ISSN (E): 2277 - 7695

ISSN (P): 2349-8242

NAAS Rating: 5.23

TPI 2021; 10(5): 1067-1075

(C) $2021 \mathrm{TPI}$

www.thepharmajournal.com

Received: 02-02-2021

Accepted: 07-03-2021

\section{Shobha D}

AICRP Post-Harvest and

Engineering Technology, GKVK,

Bangalore, Karnataka, India

Veena UK

National Academy of

Agricultural Research

Management NAARM

Hyderabad, Telangana, India

Mahadevu P

AICRP Maize, Zonal

Agricultural Research Station,

V.C. Farm, Mandya, Karnataka, India
Corresponding Author:

Shobha D

AICRP Post-Harvest and

Engineering Technology, GKVK,

Bangalore, Karnataka, India

\section{Development of gluten free pasta using Quality Protein Maize (QPM) enriched with functional ingredients}

\author{
Shobha D, Veena UK and Mahadevu P \\ DOI: https://doi.org/10.22271/tpi.2021.v10.i5n.6346
}

\begin{abstract}
In order to develop gluten free pasta using Quality Protein Maize (QPM), eight ingredients combinations(treatments) were studied, gluten free pasta prepared from quality protein maize (QPM), Black gram flour $(\mathrm{Bg})$, guar gum $(\mathrm{G})$ and enriched separately with two functional ingredients such as dehydrated carrot $(\mathrm{Ct})$ and drum stick powder (Ds) up to level of $8 \%$ was found to be acceptable organoleptically viz., (Q60:Bg30:Ct8:G2- QCt) and (Q60:Bg30:Ds8: G2- QDs) as compared to control (100\% refined wheat flour). The QPM pasta (QCt and QDs) had significantly higher weight increase index (WI), water absorption index (WAI), water solubility index (WSI) and bulk density (BD). QPM pasta exhibited less stickiness after cooking compared to control. Even the cooking loss of QPM pasta types was found to be below 8\%. The QPM pasta enriched with carrot and drumstick powders was found to be superior in nutrients such as protein $(16.2,17.3 \%)$, crude fiber $(1.8,2.4 \%)$ and low carbohydrate content (67.4 and 64.2\%) compared to control pasta. Enrichment of QPM pasta with dehydrated carrot and drumstick powders led to significant increase of calcium $(17.4,30.2 \mathrm{mg} \%)$, iron $(5.0,7.2 \mathrm{mg} \%$ ), zinc $(2.5,2.9 \mathrm{mg} \%)$ potassium $(129.6,166.7 \mathrm{mg} \%)$ and sodium $(12.8,17.3 \mathrm{mg} \%)$ contents respectively. Two types of QPM pasta stored in MPP pouches were safe for consumption until six months of storage under ambient conditions.
\end{abstract}

Keywords: Development, gluten, pasta, QPM

\section{Introduction}

Extrusion process has been reported for numerous applications including infant food, pasta, instant noodles, texturized vegetable protein, ready to eat cereals, snack products, pet food, precooked flour, meat products and many more. Pasta is one such cold extruded product which has wider acceptance worldwide. Pasta is a popular cold extruded cereal-based snack food made from moisture-enriched flour and molded into a variety of shapes such as macaroni, vermicelli and pasta. Pasta's popularity in India has grown dramatically as a result of its ease of preparation and cooking simplicity. There are currently over 30 pasta brands available in the country with a market size of around Rs. 250-300 crore (Jalgaonkar et al., 2017) ${ }^{[3]}$. Pasta is ready to cook cereal food known for its easy preparation, inexpensiveness and good sensory attributes is normally made from durum wheat semolina and is rich in dietary fiber, minerals, starch with low vitamins and phenolic compounds. Various functional ingredients have been used in recent years to improve the nutritional and functional properties of pasta. The amount of raw material that can be used as a replacement for wheat flour or applied to wheat flour represents a balance between nutritional enhancement and satisfying sensorial properties of pasta products. In India, the use of pasta products on daily basis is increasing steadily which creates a possibility to produce new types of pasta enriched with egg powder, mushroom powder and dehydrated green leafy vegetables and such attempts are increasing owning to dietary diversity and increased awareness of consumers towards nutritionally superior products. Number of studies on development of pasta using cereal legume combinations enriched with fruits, vegetables, unconventional raw materials such as addition of beetroot, carrot, green leafy vegetables have been conducted by various researchers (Alam et al. 2016; Chiu et al. 2013; Jalgaonkar et al. 2019) ${ }^{[1,6,3]}$. In this line the recent addition is gluten free products, the demand for gluten free products is increasing in the recent past owning to increase in number of people with celiac disease. Celiac disease (CD) is a chronic autoimmune disorder which is caused due to environmental and genetic factors affecting approximately 15 million consumers round the globe and occurs due to intolerance to dietary gluten, the protein found in wheat, rye and barley. Individuals with gluten intolerance are unable to absorb nutrients from products containing gluten. Thus, gluten-free products with superior nutritional 
quality, attractive colour and good shelf life are more readily accepted and gain trust among consumers. According to Food and Drug Administration, a gluten-free product is defined as food which contains less than $20 \mathrm{ppm}$ of gluten. In the recent past more and more people are opting for gluten free foods or extruded products with gluten free ingredients, due to convenience, easy digestibility, versatility, ease of preparation and long shelf life. Cereals that are naturally considered gluten free are rice, sorghum and maize (Giuberti et al. 2015) ${ }^{[8]}$. Maize is one of the three major cereal crops of the world. As a food, feed and industrial crop, it plays an important role in the global economy and trade. Maize is a vital staple food for several million people in the developing world who depend on it for their protein and energy needs (Vasal et al., 2000) ${ }^{[30]}$. Maize is a rich source of carbohydrate but low in protein quality especially lysine and tryptophan content. Because of the high levels of malnutrition around the world, many methods were devised to increase the nutritional value of staple foods like maize through biofortification. In this line, the improved maize cultivar known as Quality Protein Maize (QPM) was developed which contained nearly twice as much of the limiting amino acids as lysine and tryptophan of normal maize. QPM has been widely adopted as a maize variety that can be used to solve the issue of protein energy malnutrition in children around the world (Maseta et al., 2017) ${ }^{[17]}$. Even though country is producing large quantities of nutritionally enriched QPM varieties, the utilization of the same for human consumption is very less. In this regard, combining with good quality protein sources number of products were developed by various scientists (Shobha et al 2014, 2015, Priyanka, kumarari and Usha, singh. 2013, Chauhan and Usha Singh 2018, Pallavi Kumari and Usha Singh, 2020) [25, 26, 21, 5, 20] Traditional products prepared from maize and QPM such as dumpling, porridges, confectionaries (candies, lollipops, candy bars, chocolate,) and other sweet and savory snack food, fermented products (idli, dosa and dhokla), convenience products such as muruku, sev, laddu are some of the popular products normally prepared from maize in combination with legume flours.

The preparation of extruded products require a strong binding agent which provides strength while extrusion. Since QPM is lacking in gluten protein, it is difficult to extrude with $100 \%$ QPM flour and the best alternative is inclusion of legume flours in the preparation of extruded products like pasta. The addition of legume flours to the cereals will not only contribute for improvement in protein quality but also as a source of starch and dietary fiber, minerals along with color characteristics due to the presence of pigments in the cotyledons and seed coat. Further addition of natural functional ingredients such as green leafy vegetables, roots or tubers to pasta products will not only enhance its sensory characters but also significantly contribute for micro nutrients beyond their traditional nutrient contribution.

Micronutrients (vitamin A / $\beta$ - carotene, iodine, vitamin $\mathrm{B}_{12}$, folate, ferritin, zinc, copper and vitamin C) play an important role in the proper growth and development of the human body and its deficiency affects the health contributing to low productivity and vicious cycle of malnutrition, underdevelopment as well as poverty. Micronutrient deficiency is a public health problem affecting more than onefourth of the global population. Several programmes have been launched over the years in India to improve nutrition and health status of the population; however, a large portion of the population is still affected by micronutrient deficiency.
Anaemia, the most common form of micronutrient deficiency affects almost 50 to 60 per cent preschool children and women. In India, around 0.5 per cent of total deaths were contributed by nutritional deficiencies (Gonmei and Toteja 2018) ${ }^{[9]}$. More attention should be given for inclusion of micronutrient rich ingredients such as green leafy vegetables, roots, tubers and other vegetables into our daily diet. The common micronutrient abundant vegetables are carrot and drumstick leaves.

Carrot is known for its nutrient content viz., carotene and carotenoids, besides appreciable amounts of vitamins B1, B2, B6 and B12 and minerals. In recent years, the consumption of carrot and its products have increased steadily due to their recognition as an important source of natural antioxidants besides, anticancer activity of $\beta$-carotene being a precursor of vitamin A (Dreosti 1993; Speizer et al. 1999) ${ }^{[7,28]}$ Due to appreciable level of variety of different compounds present, carrots are considered as a functional food with significant health promoting properties (Hager and Howard 2006) ${ }^{[12]}$. Hence, carrots occupy an important place in root vegetable category for their multifaceted application which in turn, results in the development of various processing operations for making different products and/or to extend shelf-life (Gupta and Shukla, 2017) ${ }^{[11]}$.

The Moringa oleifera, native to India, grows in the tropical and subtropical regions of the world, is commonly known as 'drumstick tree' or 'horseradish tree'. The leaves are rich in minerals, vitamins and other essential phytochemicals. Extracts from the leaves are used to treat malnutrition, augment breast milk in lactating mothers. It is used as potential antioxidant, anticancer, anti-inflammatory, anti diabetic and anti microbial agent. The leaves of M. oleifera are rich in minerals like calcium, potassium, zinc, magnesium, iron and copper Vitamins like beta-carotene of vitamin A, vitamin B such as folic acid, pyridoxine and nicotinic acid, vitamin $\mathrm{C}, \mathrm{D}$ and $\mathrm{E}$ also present in $M$. oleifera. Moringa leaves also have a low calorific value and can be used in the diet of the obese and considered as functional food which promotes health (Gopalakrishnan, et al., 2016) ${ }^{[15]}$. A number of studies have also been carried out to develop pasta with enhanced nutritional attributes viz., sweet potato flour, the defatted soy flour (DSF) and soy protein concentrate (Limroongreungrat \& Huang, 2007) [16], DSF and carrot powder (Badwaik et al., 2012), cereal bran (Kaur et al.,2012) ${ }^{[14]}$, moringa leaves powder (Singh et al., 2013) ${ }^{\text {[27], pasta }}$ containing wheat: pearl millet flour (9:1) with vegetable pasta (Yadav et al., 2014) ${ }^{[31]}$. In this line the dehydrated carrot and moringa leaves, the concentrated source of micro nutrients are known for their easy availability, low cost and good sensory adaptability by the consumers were widely used in many of the food formulations such as health mixes, convenience foods, snack foods and extruded foods. However, gluten free pasta using QPM with carrot and moringa incorporation is still open for research and which further expected to increase the use of largely produced maize in our country. Hence, the present study was formulated with an objective to develop gluten free QPM pasta enriched with functional ingredients such as dehydrated carrot and drum stick powder and to evaluate its acceptability, physical, nutritional and cooking quality.

\section{Materials and Methods \\ Raw materials}

The major raw material, Quality Protein Maize (QPM) was 
obtained from Regional Maize Research Station, Begusarai, Bihar and the same was subjected to lime treatment before ground into flour as per Shobha et al. (2014) ${ }^{[25]}$. Other ingredients such as refined wheat flour and black gram flour were procured in bulk from local market and refrigerated till further use.

Preparation of Carrot and drum stick powders: Fresh carrot and drumstick leaves were washed with purified water before being blanched in hot water for three minutes (carrots were cut into thin circular slices of $2 \mathrm{~mm}$ thickness, the blanched carrot slices were immersed in 0.2 per cent KMS solution for $10 \mathrm{~min}$. The blanched drumstick leaves and carrot slices were dried at $45^{\circ} \mathrm{C}$ for 10 and 7 hours respectively using electric drier (Ezi Dri, Ultra FD 1000). The dehydrated slices and leaves were powdered separately in a domestic mixer grinder and sieved through 60 BS mesh sieve and stored in air tight pouches.

\section{Formulation of gluten free pasta}

QPM pasta was standardized using 75, 70, 65 and 60\% QPM flour (50:50 flour: semolina proportion for all the treatments) combined with various levels (T1 to T8) of blackgram flour, dehydrated carrot and drum stick powders as per Table 1. Guar gum (2\%) was used as a binding agent in all the combinations. Control pasta was extruded with 100 percent refined wheat flour (Maida).

\section{Pasta making process}

The weighed quantities of all the ingredients were sifted thoroughly in order to blend the weighted QPM-Q, black gram flour $(\mathrm{Bg})$, and guar gum $(\mathrm{G})$ followed by steaming at $100{ }^{0} \mathrm{C}$ for one hour. Since QPM lacks gluten an elastic protein, pre gelatinization and binding with pulse flour are essential to get strength to extrude and to reduce the raw taste. The extrusion was done using laboratory pasta making unit (Model: Dolly P3), kneading operation was carried out for 30 minutes after adding the appropriate amount of lukewarm water (40\% for Control and $44 \%$ for QPM). The dough was chilled for 30 minutes at $4{ }^{\circ} \mathrm{C}$. Preliminary trials were conducted to standardize the ideal steaming and refrigeration times. Different shaped dies were used to extrude chilled dough. However, owing to the lack of gluten, only the ribbed tube ( $\mathrm{S}$ shape) die retained its shape after cooking with less solid loss hence, it was chosen for further experiments. Depending on the shape of the final product, the cutter speed was adjusted to the optimal level ( 3 to $12 \mathrm{rpm}$ ). The extruded pasta was collected in trays and dried under room temperature (27-28 ${ }^{\circ} \mathrm{C}$, RH $\left.65 \%\right)$ until the final moisture content in the sample was less than $10 \%$.

\section{Sensory evaluation}

The eight different combinations of ingredients (T1 to T8) were extruded, cooked and evaluated for acceptability by a panel of 21 semi-trained judges on a 9- point hedonic scale for the sensory parameters such as appearance, colour, texture, mouth feel and overall acceptability. Pasta was cooked in water with a standardized amount of spice mixture for the specified amount of time. The best accepted combination of carrot and drumstick powder incorporated QPM pasta were compared with control.

\section{Colour and Texture analysis of pasta}

The spectrophotometer (Konica Minolta Instrument Osaka,
Japan Model-CM 5) was used to measure the surface colour of cooked and uncooked pasta samples. The CIE scheme was used to define colour coordinates $\left(\mathrm{L}^{*}, \mathrm{a}^{*}, \mathrm{~b}^{*}\right)$. Cooked pasta was thoroughly dried with absorbent paper before being measured. Texture Analyzer (Stable Microsystems Ltd, UK; model-HDi) was used to measure the firmness and adhesiveness of pasta types (Carrot added QPM pasta-QCt, drumstick powder added QPM pasta-QDs, and Control). Pasta samples were cooked to optimum cooking time (OCT), drained and allowed to rest for 10 minutes for texture analysis with a pre-test speed of $1.5 \mathrm{~mm} / \mathrm{s}$ with a test speed of $2 \mathrm{~mm} / \mathrm{s}$ and post-test speed of $10 \mathrm{~mm} / \mathrm{s}$. Pasta strands were sliced with blade set with knife to determine hardness and adhesiveness (cooked pasta). Five measurements were taken for each sample and average value was calculated.

\section{Cooking and physical parameters of pasta}

According to Rodriguez-Miranda et al (2011) ${ }^{[23]}$ various cooking parameters of the best accepted pasta were determined which includes optimum cooking time (OCT), swelling index (SI), cooking loss (CL), cooked volume (CV), cooked weight $(\mathrm{CW})$, and weight increase index (WI). The physical parameters such as water absorption index, water solubility index, bulk density and expansion ratio were assessed as per Benhur et al. (2015) ${ }^{[3]}$.

\section{Nutritional analysis of pasta}

The proximate analysis of the pasta samples was determined as per Raghuramulu et al. (2003) ${ }^{[22]}$. The minerals such as calcium, copper, zinc, iron, and manganese were estimated using Atomic absorption spectrophotometer (AAS: Agilent Technologies Series AA).

\section{Shelf life study of pasta samples}

The best-accepted pasta (QCt, QDs and Control) were packed in metalized polyester polyethylene (MPP) pouches and stored for a period of six months at ambient temperature (26$28^{\circ} \mathrm{C}$ ) and assessed for changes in biochemical parameters (moisture, peroxide value, free fatty acid) and microbial load.

\section{Statistical analysis}

The Duncan test was used to determine the variations in different types of pasta samples (P\0.05). The R software ( $R$ studio) was used to statistically interpret the data for various parameters.

\section{Results and Discussion \\ Organoleptic evaluation of pasta}

Organoleptic evaluation of different ingredient combinations (T1 to T8) revealed that there were significant differences between the treatments. As the level of QPM increased (T1T6) due to strong starchy mouth coating and distinct maize flavour, sensory scores decreased (Fig.1a) while, T7 (Q60:Bg30:Ct8:G2- QCt) and T8 (Q60:Bg30:Ds8: G2-QDs) too exhibited a starchy mouth coating however, it was within the level of acceptability (7.3 and 7.5 on 9-point scale). The use of pre treatments such as steaming and refrigeration methods prior to extrusion helped to hydrate the starch, resulting into decline of the distinctive starchy flavour of maize and stickiness of cooked pasta. The QCt and QDs were further compared with control (Fig 1b) and the results showed that the control was ranked between very good to excellent compared to QCt and QDs which is understandable that the control pasta was produced with refined wheat flour which is 
devoid of fibre and had glossy appearance resulting in higher sensory scores, while the QPM pasta was a blend of whole maize flour and semolina had rough surface further, the inclusion of carrot and drumstick powder decreased the colour and appearance scores (Fig 1 b). Due to absence of gluten in maize flour, the addition of gum and black gram flour to QPM resulted in the production of rupture-free pasta of good consistency. Previous researchers (Romero et al. 2017; Mirhosseini et al. 2015) ${ }^{[24,19]}$ confirmed that the addition of gums like xanthan gum and guar gum to gluten-free pasta improved the colour, elasticity and overall quality.

\section{Cooking and physical parameters of pasta}

Three different varieties of pasta samples showed significant differences with respect to physical and cooking parameters (Table 2). The swelling index of QPM pasta (QCt and QDs) was slightly higher $(3.5$ and $3.1 \mathrm{~g} / \mathrm{g}$ ) as compared to control $(2.6 \mathrm{~g} / \mathrm{g})$. Even the cooked weight and volume for $\mathrm{QCt}$ and QDs were considerably higher (Table 2). Cooking loss, a critical quality metric for pasta quality is significantly low for control (6.1\%) followed by QCt (7.3\%), and QDs (7.1\%). The cooking loss in pasta samples should be less than $8 \%$ according to BIS norm [BIS: 1485 (2010)] and the cooking loss in the three pasta types in this study was less than $8 \%$. The lack of gluten protein in QPM led to higher cooking loss in QPM-based pasta. Since the gluten protein network is responsible for maintaining the functional integrity of pasta during cooking a weaker sector leaches more solids from pasta samples into the cooking broth resulting into increased cooking residue (Gull et al., 2015) ${ }^{[10]}$. As compared to control, the weight increase index, water absorption index and water solubility index were significantly higher for QPM pasta (QCt and QDs) which was due to the QPM's inherent property of higher water absorption efficiency as reported in our previous work (Shobha et al.,2015) ${ }^{[26]}$. In comparison to control pasta, QPM pasta (QCt and QDs) had significantly higher weight increase index (WI), water absorption index (WAI), water solubility index (WSI), and bulk density (BD). The differences in WAI of extrudates may be due to protein denaturation, starch gelatinization, and coarse fibre swelling during extrusion. Increase in the value of WAI may probably be caused by uncovering of hydrophilic groups in extruded starch-protein material by unfolding and loosening of biopolymer mechanism led to greater availability and easier penetration of structures by water molecules (Mesquita et al. 2013) ${ }^{[18]}$. The Water solubility index (WSI) measures the degree of starch conversion which is the amount of soluble polysaccharides released from the starch during extrusion (Alam et al. 2016) ${ }^{[1]}$. The WSI varied from $5.70 \%$ (control) to $7.4 \%(\mathrm{QCt})$ and $7.8 \%$ (QDs) implying that adding legume flour to QPM-based pasta led to increased WSI (Table 2).

\section{Color and texture analysis of pasta}

The non-enzymatic browning reaction (Maillard reaction, sugar caramalization) and pigment degradation cause colour degradation during the extrusion process. The colour of uncooked and cooked QPM pasta enriched with carrot and drum stick powder were compared in this study (Table 3). In both uncooked and cooked pasta samples, lightness $\mathrm{L}^{*}$ decreased slightly as the amount of QPM flour in the recipe was increased. Control pasta had slightly higher $\mathrm{L}^{*}$ value (76.4) than QCt and QDs. Pasta enriched with drumstick powder had significantly lower lightness value compared to rest of the samples tested (Table 3 ). The a* value indicated that QCt pasta was significantly more redness value in cooked and uncooked samples which may be attributed to the carotenoid content in carrot powder. In carrot enriched QPM pasta, the $\mathrm{b}^{*}$ (yellowness) is also significantly higher (Table 3). Differences in the colored pigments of QPM, black gram flour, carrot powder, and drumstick powder accounted for differences in the colour characteristics of pasta samples.

The key criterion for determining the overall quality of pasta is its texture which contributes for mouth feel hence, textural qualities of pasta are becoming more relevant to customers. In comparison to QCt $(43.0 \mathrm{~N})$ and QDs $(39.7 \mathrm{~N})$ control pasta had significantly highest hardness value $(73.6 \mathrm{~N})$.Variations between control, QCt, and QDs were found to be significant ( $p<0.05$ ) with respect to texture. When compared to control, cooked QCt and QDs had significantly lower adhesiveness values indicating that QPM pasta is less sticky than refined wheat flour pasta (Table 3). The expansion ratio and density are usually inversely related (Tanska et al. 2017) ${ }^{[29]}$. The presence of fibre particles continued to rupture the cell wall before the starch had expanded to its maximum potential resulting in higher bulk density in QPM pasta types (Table 2) due to less expansion and more impact. In this study, QPM pasta enriched with carrot $(\mathrm{QCt})$ and drumstick powders (QDs) had higher bulk density and lower expansion ratio. Since protein and starch compete for water, starch gelatinization is diminished or delayed in QPM pasta enriched with carrot and drum stick powder; the reduced expansion ratio can be predicted as a result of increased protein content.

\section{Nutritional composition of pasta samples}

The moisture content in control and QPM pasta (QCt and QDs) was 8.2 and $8.8 \%$ indicating that the moisture level was $<10 \%$ in all pasta types which was ideal for longer shelf life (Table 4). The QPM-based carrot and drumstick added pasta had significantly higher crude protein (16.2 and 17.3\%), crude fibre (1.84 and 2.4\%), and ash content (2.0 and 2.2\%) for QCt and QDs respectively (Table 4). The addition of black gram flour to the formulation coupled with enrichment of carrot and drum stick powders resulted into increase of above nutrients. Drumstick pasta (QDs) had significantly higher calcium, iron, potassium, and sodium content (Table 5), which was due to the fact that drum stick leaves are an excellent source of many of these minerals. The data clearly showed that the Organoleptic quality of control pasta is very high (Fig1 b) as compared to QCt and QDs pasta, but the inclusion of carrot and drumstick powders improved the micro nutritional quality significantly.

\section{Shelf life study of pasta samples}

The variations in moisture content of pasta during storage are depicted in Fig.2. During storage of pasta there was no discernible trend in moisture content. However, after three months of storage, QDs showed a significant increase in moisture content and values were found to be non significant. Peroxide and free fatty acids (FFA) levels increased steadily in all pasta types but the rise was more dramatic in QCt due to higher fat and beta carotene content which led to an increase in FFA and peroxide values however, the levels were within normal limits so that the taste, flavour, and acceptability of the pasta were not affected. In fresh pasta samples stored in MPP packets, the bacterial population of three types of pasta was found to be zero (Data not shown). However, after one month a steady increase in bacterial count was noticed which continued for six months of storage. No fungal population 
was noticed in any of the pasta types. Over a period of six months of storage, no E. coli existed in any of the samples. According to coli form examination, the appearance of $E$. coli in any foods is unfavorable, as it indicates poor hygienic issues, contamination, or inadequate heat treatment. The microbial examination revealed that the low moisture content of the pasta (below ten percent) as well as the method used to prepare and store the pasta product was considered to be microbiologically safe and the most hygienic methods were adopted in the current investigation.

Table 1: Different combination of ingredients (treatments) for standardization of pasta

\begin{tabular}{|c|c|c|c|c|c|}
\hline Treatments & $\begin{array}{c}\text { QPM- Q } \\
(\boldsymbol{\%})\end{array}$ & $\begin{array}{c}\text { Black gram flour (Bg) } \\
\text { \% }\end{array}$ & $\begin{array}{c}\text { Carrot powder } \\
(\mathbf{C t )} \boldsymbol{\%}\end{array}$ & $\begin{array}{c}\text { Drum stick powder } \\
\text { (Ds) \% }\end{array}$ & Guar gum (gum) \% \\
\hline T1 & 75 & 18 & 5 & - & 2 \\
\hline T2 & 75 & 18 & - & 5 & 2 \\
\hline T3 & 70 & 20 & 8 & - & 2 \\
\hline T4 & 70 & 20 & -- & 8 & 2 \\
\hline T5 & 65 & 23 & 10 & --- & 2 \\
\hline T6 & 65 & 23 & --- & 10 & 2 \\
\hline T7 & 60 & 30 & 8 & --- & 2 \\
\hline T8 & 60 & 30 & ---- & 8 & \\
\hline
\end{tabular}

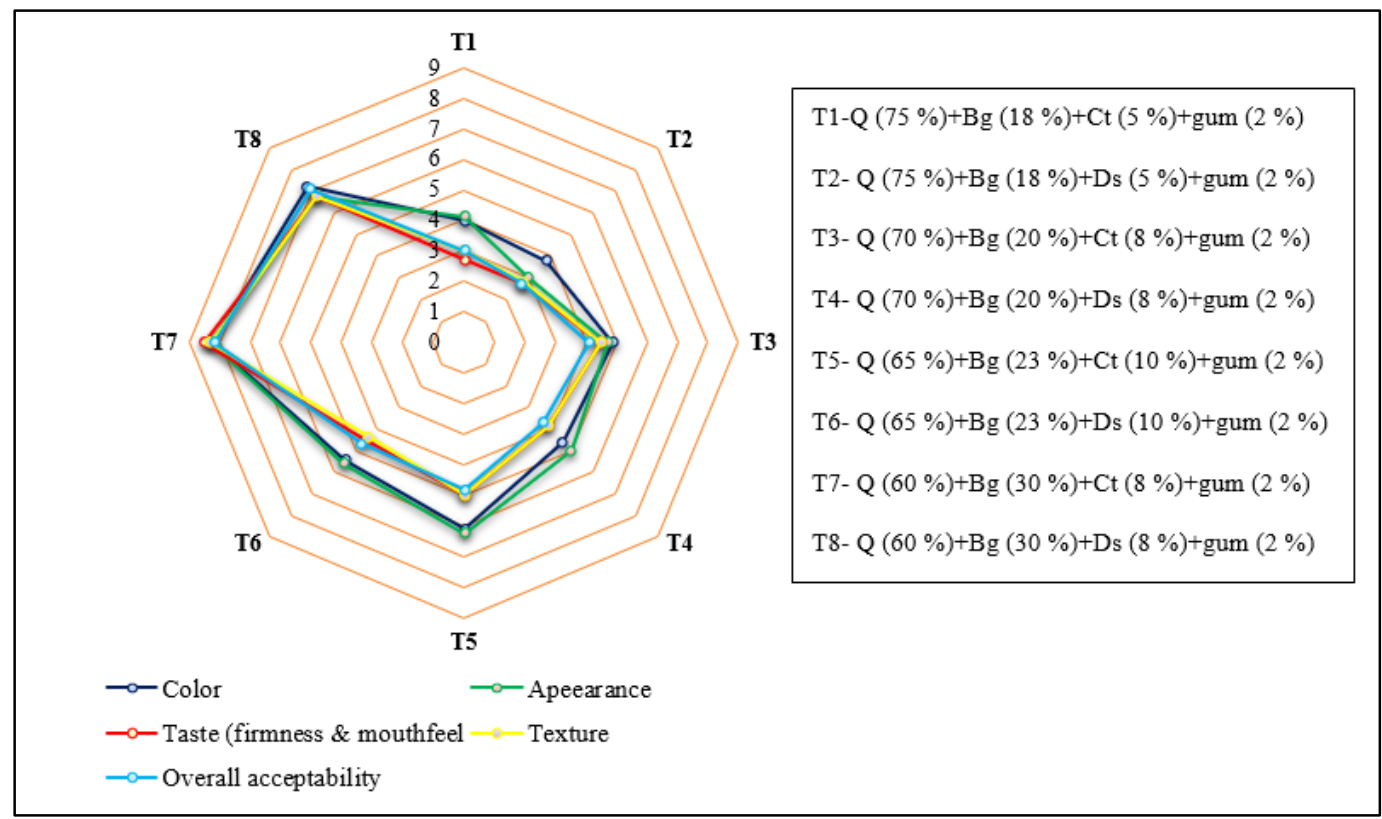

A

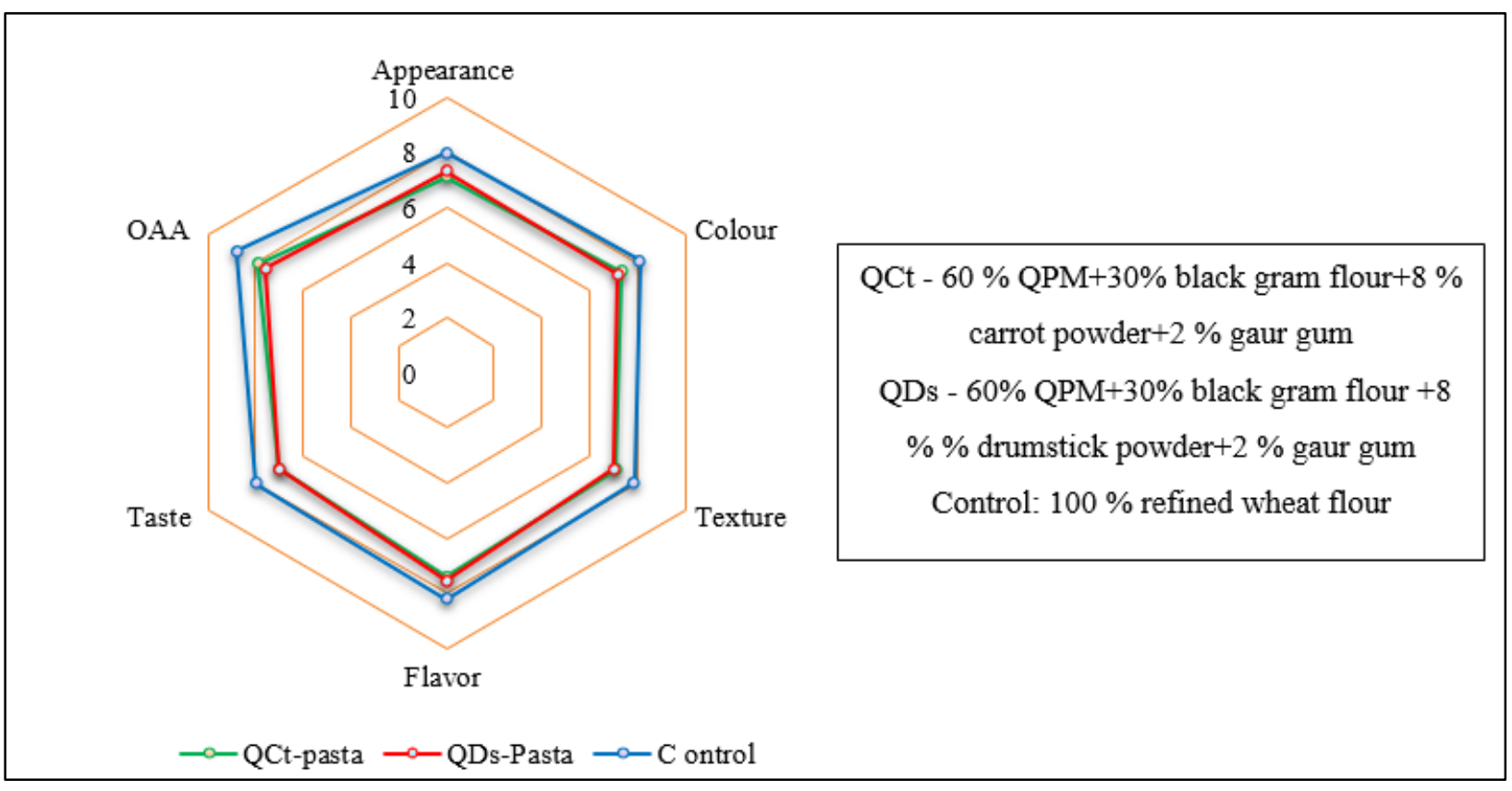

B.

Fig 1: Sensory evaluation of pasta a) Sensory scores of different formulations (treatments) of pasta with ingredient variations and b) Sensory scores of QPM pasta compared to control. 
Table 2: Cooking and physical parameters of developed pasta

\begin{tabular}{|c|c|c|c|c|c|c|c|c|c|c|}
\hline & \multicolumn{5}{|c|}{ Cooking properties } & & \multicolumn{4}{|c|}{ Physical parameters } \\
\hline Pasta samples & $\begin{array}{c}\text { OCT } \pm \text { SD } \\
(\text { min })\end{array}$ & $\begin{array}{c}\mathrm{SI} \pm \mathrm{SD} \\
(\mathrm{g} / \mathrm{g})\end{array}$ & $\begin{array}{c}\text { CL } \pm \text { SD } \\
(\%)\end{array}$ & $\begin{array}{c}\mathrm{CV} \pm \mathrm{SD} \\
(\%)\end{array}$ & $\begin{array}{l}\mathrm{CW} \pm \\
\mathrm{SD}(\mathrm{g})\end{array}$ & $\mathrm{WI} \pm \mathrm{SD}$ & $\begin{array}{c}\text { WAI } \pm \text { SD } \\
(\mathrm{g} / \mathrm{g})\end{array}$ & $\begin{array}{c}\text { WSI } \pm \text { SD } \\
(\%)\end{array}$ & $\begin{array}{c}\mathrm{BD} \pm \mathrm{SD} \\
\left(\mathrm{kg} / \mathrm{m}^{3}\right)\end{array}$ & $\mathbf{E R} \pm \mathbf{S D}$ \\
\hline Control pasta & $6.2^{\mathrm{c}} \pm 0.05$ & $2.6^{\mathrm{c}} \pm 0.03$ & $6.1^{\mathrm{c}} \pm 0.02$ & $1.9 \pm 0.2$ & $9.9^{c} \pm 0.15$ & $2.04^{\mathrm{b}} \pm 0.02$ & $4.8^{\mathrm{b}} \pm 0.13$ & $5.7^{\mathrm{c}} \pm 0.1$ & $0.53^{\mathrm{c}} \pm 0.003$ & $9.2^{\mathrm{a}} \pm 0.05^{*}$ \\
\hline Carrot pasta (QCt) & $7^{\mathrm{a}} \pm 0.2^{*}$ & $3.5^{\mathrm{a}} \pm 0.03^{*}$ & $7.3^{\mathrm{a}} \pm 0.03^{*}$ & $2.1 \pm 0.12$ & $13^{\mathrm{a}} \pm 0.2 *$ & $2.6^{\mathrm{a}} \pm 0.2^{*}$ & $5.8^{\mathrm{a}} \pm 0.06^{*}$ & $7.8^{\mathrm{a}} \pm 0.1 *$ & $0.58^{\mathrm{a}} \pm 0.0 * 03$ & $8.9^{\mathrm{b}} \pm 0.1$ \\
\hline Drumstick pasta (QDs) & $6.47^{\mathrm{b}} \pm 0.02$ & $3.1^{\mathrm{b}} \pm 0.03$ & $7.1^{\mathrm{b}} \pm 0.03$ & $2.15 \pm 0.13$ & $12.4^{\mathrm{b}} \pm 0.3$ & $2.5^{\mathrm{a}} \pm 0.1^{*}$ & $5.6^{\mathrm{a}} \pm 0.2 *$ & $7.4^{\mathrm{b}} \pm 0.1$ & $0.56^{\mathrm{b}} \pm 0.004$ & $8.7^{b} \pm 0.2$ \\
\hline F-value & $34 *$ & $529 *$ & $1379 *$ & NS & $128 *$ & $15 *$ & $45 *$ & $193 *$ & $144 *$ & $10 *$ \\
\hline S.Em \pm & 0.069 & 0.06 & 0.018 & & 0.144 & 0.07 & 0.08 & 0.07 & 0.002 & 0.07 \\
\hline $\mathrm{CD}$ at $5 \%$ & 0.244 & 0.019 & 0.062 & & 0.508 & 0.27 & 0.28 & 0.27 & 0.007 & 0.26 \\
\hline
\end{tabular}

OCT: optimum cooking time, SI: swelling index, CL: cooking loss, CV: cooked volume, CW: cooked weight, WI: weight increase index, WAI: water absorption index, WSI: water solubility index, BD: bulk density, ER: expansion ratio, *significant at 5\% $(p<0.05)$ and SD standard deviation for three determinations and data followed by different letters (a-c) within the same column indicate statistically significant difference at $5 \%(p<0.05)$ between the results and the same letter were not significantly different $(\mathrm{p}=0.05)$.

Table 3: Color and texture analysis of pasta

\begin{tabular}{|c|c|c|c|c|c|c|c|c|c|}
\hline & \multicolumn{2}{|c|}{$\mathbf{L}^{*}$} & \multicolumn{2}{|c|}{$\mathbf{a}^{*}$} & \multicolumn{2}{|c|}{$\mathbf{b}^{*}$} & \multicolumn{2}{|c|}{ Hardness (N) } & Adhesiveness (g.sec) \\
\hline Pasta samples & Uncooked & Cooked & Uncooked & Cooked & Uncooked & Cooked & Uncooked & Cooked & Cooked \\
\hline Control pasta & $76.4^{\mathrm{a}} \pm 0.3^{*}$ & $63.2^{\mathrm{a}} \pm 0.7 *$ & $1.2^{\mathrm{c}} \pm 0.02$ & $0.5^{\mathrm{c}} \pm 0.03$ & $18.4^{\mathrm{c}} \pm 0.2$ & $13.9^{c} \pm 0.04$ & $73.6^{\mathrm{a}} \pm 1.5 *$ & $2.5^{\mathrm{a}} \pm 0.03 *$ & $-1.2^{\mathrm{c}} \pm 0.02$ \\
\hline Carrot pasta $(\mathrm{QCt})$ & $63.5^{\mathrm{b}} \pm 0.2$ & $52.9^{\mathrm{b}} \pm 0.5$ & $9.5^{\mathrm{a}} \pm 0.3^{*}$ & $4.7^{\mathrm{a}} \pm 0.06^{*}$ & $30.7^{\mathrm{a}} \pm 0.0 *$ & $18.4^{\mathrm{a}} \pm 0.0^{*}$ & $43^{b} \pm 0.5$ & $1.1^{\mathrm{c}} \pm 0.03$ & $-0.02^{\mathrm{a}} \pm 0.001^{*}$ \\
\hline Drumstick pasta (QDs) & $52.7^{\mathrm{c}} \pm 0.2$ & $40.3^{\mathrm{c}} \pm 0.5$ & $3.4^{\mathrm{b}} \pm 0.2$ & $2.8^{\mathrm{b}} \pm 0.06$ & $18.9^{\mathrm{b}} \pm 0.05$ & $16.8^{\mathrm{b}} \pm 0.1$ & $39.7^{\mathrm{c}} \pm 0.03$ & $1.5^{\mathrm{b}} \pm 0.02$ & $-0.11^{\mathrm{b}} \pm 0.01$ \\
\hline F-value & $5791 *$ & $1055^{*}$ & $915^{*}$ & $4756^{*}$ & $11615^{*}$ & $3590 *$ & $1239 *$ & $1777 *$ & $4997 *$ \\
\hline S.Emt & 0.15 & 0.3 & 0.13 & 0.03 & 0.06 & 0.03 & 0.5 & 0.01 & 0.009 \\
\hline $\mathrm{CD}$ at $5 \%$ & 0.55 & 1.2 & 0.46 & 0.1 & 0.22 & 0.13 & 1.8 & 0.05 & 0.03 \\
\hline
\end{tabular}

L*: brightness, a*: redness, $b^{*}$ : yellowness, Where, 'a' +ve = redness, 'a' -ve = greenness, 'b' +ve = yellowness, 'b' -ve = blueness, N: Newton, SD standard deviation for three determinations, * significant at $5 \%(p<0.05)$ and data followed by different letters (a-f) are significantly different at $5 \%(p<0.05)$ and the same letter were not significantly different $(\mathrm{p}=0.05)$.

Table 4: Proximate composition of developed pasta

\begin{tabular}{|c|c|c|c|c|c|c|c|}
\hline Pasta samples & Moisture \pm SD (g) & Protein \pm SD $(g)$ & Fat \pm SD $(g)$ & Crude fiber \pm SD $(g)$ & Ash \pm SD (g) & $\mathrm{CHO} \pm \mathrm{SD}(\mathrm{g})$ & Energy \pm SD (kcal) \\
\hline Control pasta & $8.4^{\mathrm{b}} \pm 0.01$ & $9^{c} \pm 0.05$ & $1.1^{\mathrm{b}} \pm 0.02$ & $0.9^{c} \pm 0.01$ & $0.9^{b} \pm 0.01$ & $79^{\mathrm{a}} \pm 0.7^{*}$ & $365.6 \pm 1$ \\
\hline Carrot pasta $(\mathrm{QCt})$ & $8.2^{\mathrm{c}} \pm 0.02$ & $16.2^{\mathrm{b}} \pm 0.8$ & $3^{\mathrm{a}} \pm 0.2^{*}$ & $1.8^{\mathrm{b}} \pm 0.04$ & $2^{\mathrm{a}} \pm 0.11 *$ & $67.4^{\mathrm{b}} \pm 0.9$ & $368.8 \pm 1.1$ \\
\hline Drumstick pasta (QDs) & $8.8^{\mathrm{a}} \pm 0.05$ & $17.3^{\mathrm{a}} \pm 0.4^{*}$ & $3.3^{\mathrm{a}} \pm 0.3^{*}$ & $2.4^{\mathrm{a}} \pm 0.4^{*}$ & $2.2^{\mathrm{a}} \pm 0.2^{*}$ & $64.2^{c} \pm 0.9$ & $366 \pm 1.8$ \\
\hline F-value & $225 *$ & $225^{*}$ & $82 *$ & $25^{*}$ & $98 *$ & $230^{*}$ & NS \\
\hline S.Em \pm & 0.02 & 0.3 & 0.13 & 0.15 & 0.07 & 0.5 & \\
\hline $\mathrm{CD}$ at $5 \%$ & 0.07 & 1 & 0.46 & 0.54 & 0.25 & 1.8 & \\
\hline
\end{tabular}

CHO: carbohydrate, * significant at $5 \%(p<0.05)$, SD standard deviation for three determinations and data followed by different letters (a-e) within the same column indicate statistically significant difference at $5 \%(p<0.05)$ between the results and the same letter were not significantly different $(\mathrm{p}=0.05)$.

Table 5: Mineral composition of developed pasta samples

\begin{tabular}{|c|c|c|c|c|c|c|c|c|}
\hline & \multicolumn{9}{|c|}{ Minerals } \\
\hline Pasta samples & $\begin{array}{c}\mathbf{C a} \pm \text { SD } \\
(\mathbf{m g})\end{array}$ & $\begin{array}{c}\mathbf{C u} \pm \text { SD } \\
(\mathbf{m g})\end{array}$ & $\begin{array}{c}\mathbf{Z n} \pm \text { SD } \\
(\mathbf{m g})\end{array}$ & $\begin{array}{c}\mathbf{F e} \pm \text { SD } \\
(\mathbf{m g})\end{array}$ & $\begin{array}{c}\mathbf{P} \pm \text { SD } \\
(\mathbf{m g})\end{array}$ & $\begin{array}{c}\mathbf{M n} \pm \text { SD } \\
(\mathbf{m g})\end{array}$ & $\begin{array}{c}\mathbf{K} \pm \text { SD } \\
(\mathbf{m g})\end{array}$ & $\begin{array}{c}\mathbf{N a} \pm \text { SD } \\
(\mathbf{m g})\end{array}$ \\
\hline Control pasta & $3.5^{\mathrm{c}} \pm 0.5$ & $0.42^{\mathrm{b}} \pm 0.01$ & $1.12^{\mathrm{c}} \pm 0.02$ & $2^{\mathrm{c}} \pm 0.1$ & $200.2^{\mathrm{b}} \pm 6.5$ & $1.7^{\mathrm{a}} \pm 0.02^{*}$ & $71.2^{\mathrm{c}} \pm 1.8^{*}$ & $8.9^{\mathrm{c}} \pm 0.5$ \\
\hline Carrot pasta (QCt) & $17.4^{\mathrm{b}} \pm 1$ & $0.65^{\mathrm{a}} \pm 0.03^{*}$ & $2.5^{\mathrm{b}} \pm 0.1$ & $5^{\mathrm{b}} \pm 0.2$ & $382.6^{\mathrm{a}} \pm 3.4^{*}$ & $0.39^{\mathrm{c}} \pm 0.02$ & $129.6^{\mathrm{b}} \pm 1.7$ & $12.8^{\mathrm{b}} \pm 0.5^{*}$ \\
\hline Drumstick pasta (QDs) & $30.2^{\mathrm{a}} \pm 1.2^{*}$ & $0.48^{\mathrm{b}} \pm 0.04$ & $2.9^{\mathrm{a}} \pm 0.06^{*}$ & $7.2^{\mathrm{a}} \pm 0.5^{*}$ & $387.6^{\mathrm{a}} \pm 7.4^{*}$ & $1.4^{\mathrm{b}} \pm 0.03$ & $166.7^{\mathrm{a}} \pm 5.2^{*}$ & $17.3^{\mathrm{a}} \pm 1^{*}$ \\
\hline F-value & $589^{*}$ & $38^{*}$ & $327^{*}$ & $171^{*}$ & $931^{*}$ & $2327^{*}$ & $104^{*}$ & $104^{*}$ \\
\hline S.Em \pm & 0.5 & 0.019 & 0.05 & 0.2 & 3.5 & 0.014 & 0.41 & 0.41 \\
\hline CD at 5\% & 1.9 & 0.067 & 0.18 & 0.7 & 12.3 & 0.049 & 1.45 & 1.45 \\
\hline
\end{tabular}

Ca: calcium, $\mathrm{Cu}$ : cupper, $\mathrm{Zn}$ : zinc, Fe: iron, P: phosphorous, Mn: manganese, K: potassium and Na: sodium, *significant at $5 \%(p<0.01), \mathrm{SD}$ standard deviation for three determinations and data followed by different letters (a-c) within the same column indicate statistically significant difference at $5 \%(p<0.05)$ between the results and the same letter were not significantly different $(\mathrm{p}=0.05)$. 


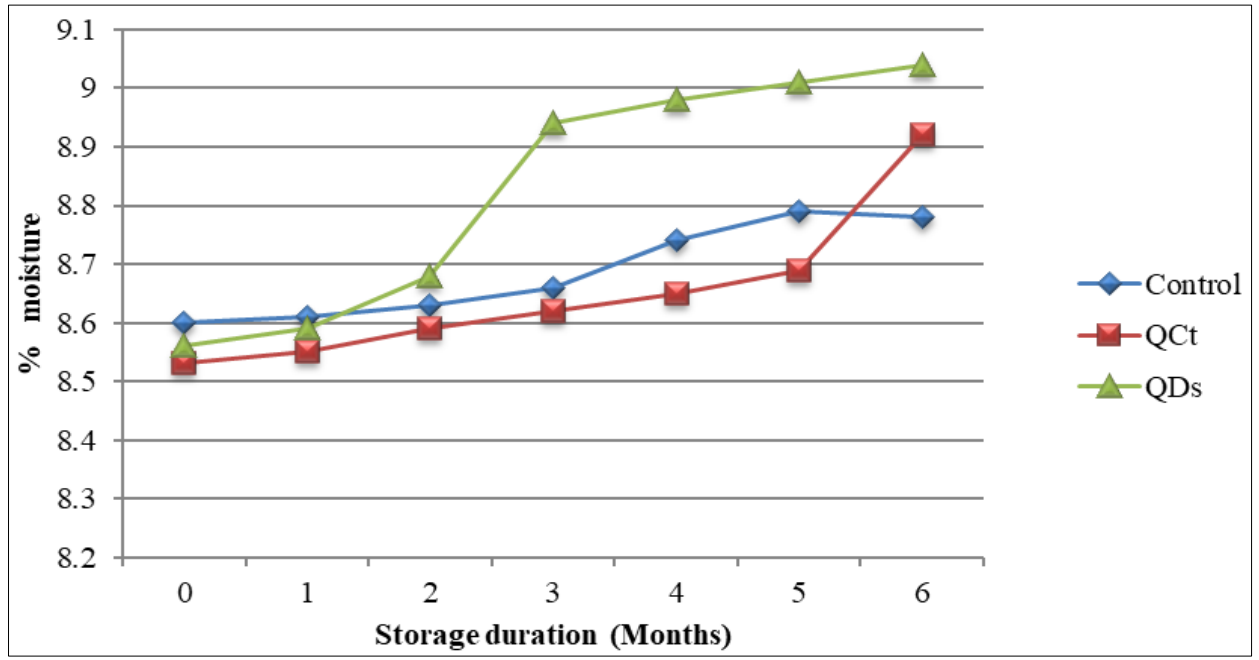

A.

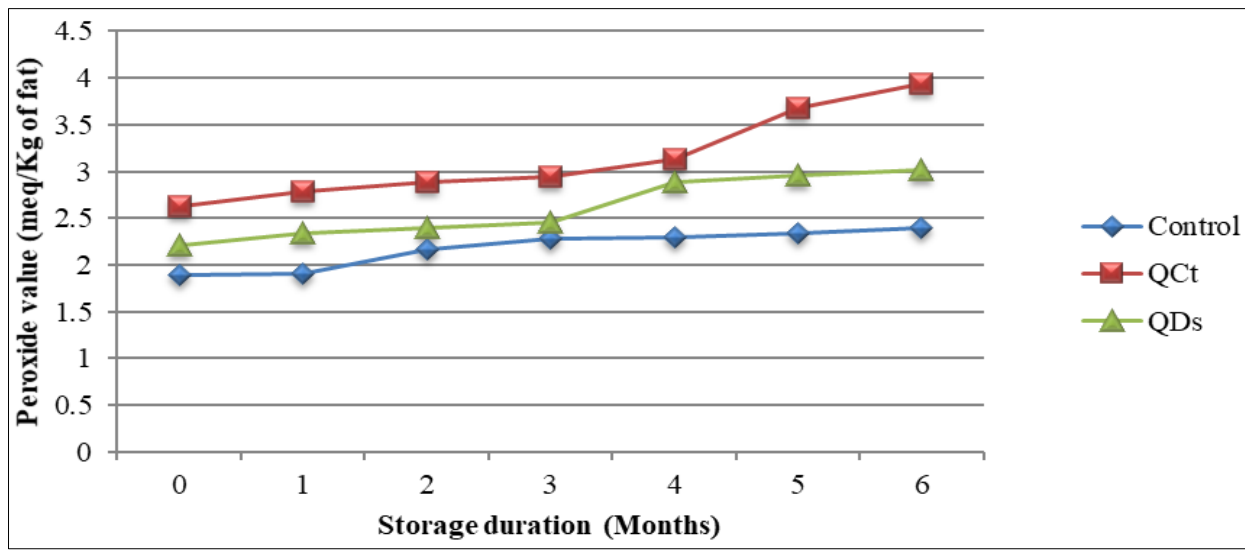

B.

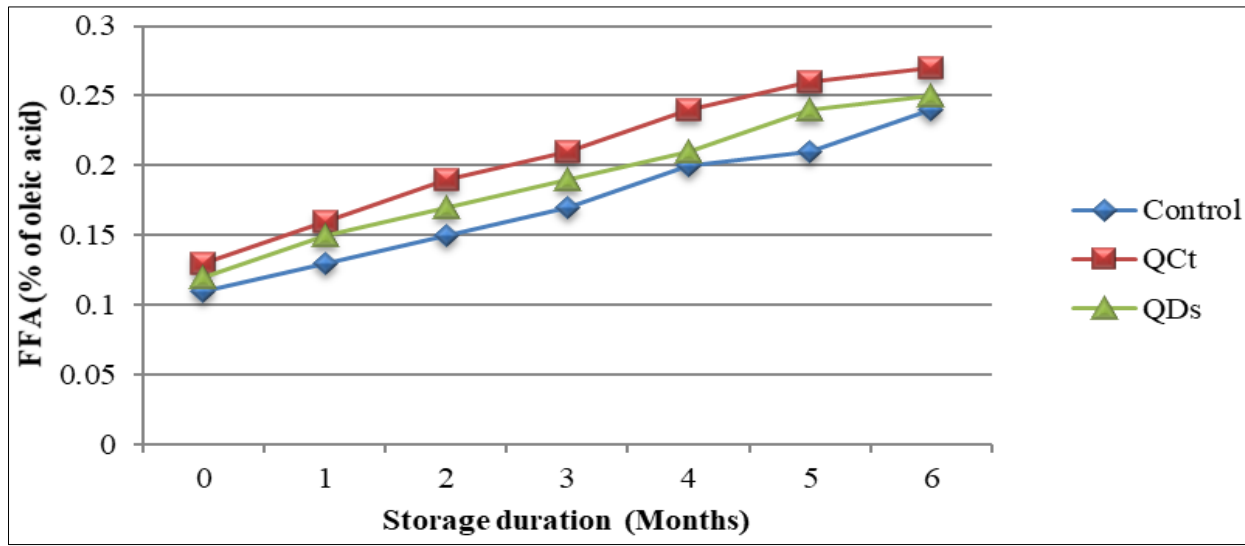

Fig 2: Shelf life study of the best accepted pasta a) Moisture, b) Peroxide value and c) Free fatty acid value of pasta during storage

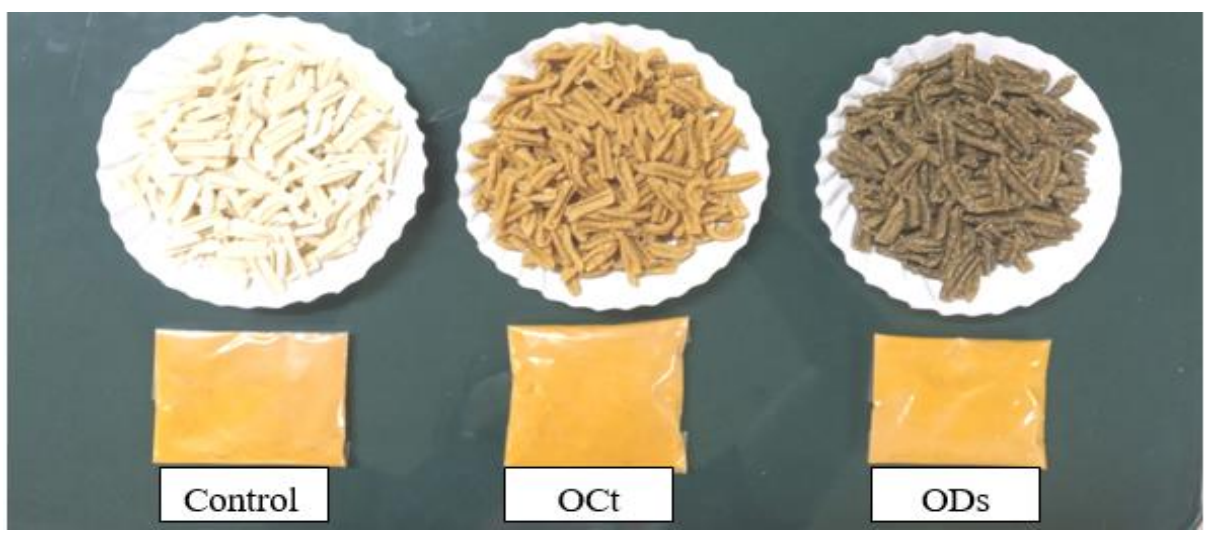

Plate 1: Images of Control, Carrot incorporated QPM pasta (QCt), Drumstick incorporated QPM pasta (QDs) along with the spice mixture $\sim 1073 \sim$ 


\section{Conclusion}

Study revealed that the QPM was found suitable for the development of gluten free pasta by suitably combining with pulse flour and guar gum. Further, enrichment with functional ingredients such as dehydrated carrot and drum stick powders has lead to improvement in micro nutrient content in terms of calcium, iron, zinc, sodium and potassium. The QPM pasta had significantly higher weight increase index (WI), water absorption index (WAI), water solubility index (WSI) and bulk density (BD) and exhibited less stickiness after cooking compared to refined wheat flour pasta. Even the cooking loss of QPM pasta types was found to be below $8 \%$ which was desirable pasta attribute. The developed QPM pasta (QCt and QDs) can be consumed as gluten-free breakfast item suitable for normal as well as gluten-allergic consumers.

\section{Acknowledgements}

The authors are grateful to Dr. Ramesh Kumar Phagna Principle Scientist (Plant Breeding) ICAR-Indian Institute of Maize Research, Ludhiana for providing QPM grains for research work

\section{References}

1. Alam MS, Pathania S, Sharma A. Optimization of the extrusion process for development of high fibre soybean-rice ready-to-eat snacks using carrot pomace and cauliflower trimmings. Food Science \& Technology. 2016;74:135-144.

2. Badwaik LS, Prasad K, Seth D. Optimization of ingredient levels for the development of peanut based fiber rich pasta. Journal of Food Science and technology. 2014;51(10):2713-2719.

3. Benhur DR, Bhargavi G, Kalpana K, Vishala AD, Ganapathy KN, Patil JV. Development and standardization of sorghum pasta using extrusion technology. Journal of Food Science and Technology 2015;52(10):6828-6833.

4. BIS, 1485 Macaroni, Spaghetti, Vermicelli and Egg Noodles Specification. Second revision. Bureau of Indian Standards. New Delhi 2010.

5. Chauhan, Saloni, Usha, Singh. Changes in Glycemic Index in Quality Protein Maize Based Flour Before and After Processing Under In Vitro Condition. International Journal of Current

Microbiology and Applied Sciences 2018;7(11):26132621.

6. Chiu HW, Peng JC, Tsai SJ, Tsay JR, Lui WB. Process optimization by response surface methodology and characteristics investigation of corn extrudate fortified with yam (Dioscorea alata L.). Food and Bioprocess Technology 2013;6(6):1494-1504.

7. Dreosti IE, Les vitamines AC et al. bêta-carotène comme facteurs protecteurs de certains cancers. Asia Pacific Journal of Clinical Nutrition 1993;2:5-21.

8. Giuberti G, Gallo A, Cerioli C, Fortunati P, Masoero F. Cooking quality and starch digestibility of gluten free pasta using new bean flour. Food Chemistry 2015;175:43-49.

9. Gonmei, Zaozianlungliu, Toteja GS. Micronutrient status of Indian population. Indian Journal of Medical Research 2018;148(5):511-521.

10. Gull A, Prasad K, Kumar P. Effect of millet flours and carrot pomace on cooking qualities, color and texture of developed pasta. LWT-Food Science and
Technology. 2015;63(1):470-474.

11. Gupta, Shukla. Journal of Food Processing \& Technology 2017;8:9 (DOI: 10.4172/2157-7110.1000692).

12. Hager TJ, Howard LR. Processing effects on carrot phytonutrients. Horticultural Science 2006;41(1):7479.

13. Jalgaonkar K, Jha SK, Mahawar MK, Yadav DN. Pearl millet based pasta: optimization of extrusion process through response surface methodology. Journal of Food Science and Technology 2019;56(3):1134-1144.

14. Kaur G, Sharma S, Nagi HPS, Dar BN. Functional properties of pasta enriched with variable cereal brans. Journal of food science and technology. 2012;49(4):467-474.

15. Lakshmipriya, Gopalakrishna NB, Kruthi, Doriyaa, Devarai, Santhosh Kumar. Moringa oleifera: A review on nutritive importance and its medicinal application. Food Science and Human Wellness 2016;5:49-56.

16. Limroongreungrat K, Huang YW. Pasta products made from sweet potato fortified with soy protein. LWTFood Science and Technology 2007;40(2):200-206.

17. Maseta E, Mosha TC, Nyaruhucha C, Laswai $H$. Nutritional quality of quality protein maize-based supplementary foods. Nutrition \& Food Science 2017.

18. Mesquita CDB, Leonel M, Mischan MM. Effects of processing on physical properties of extruded snacks with blends of sour cassava starch and flaxseed flour. Food Science and Technology 2013;33(3):404-410.

19. Mirhosseini H, Rashid NFA, Amid BT, Cheong KW, Kazemi M, Zulkurnain M. Effect of partial replacement of corn flour with durian seed flour and pumpkin flour on cooking yield, texture properties, and sensory attributes of gluten free pasta. Food Science and Technology 2015;63(1):184-190.

20. Pallavi, Kumari, Usha, Singh. Nutritional Value and Acceptability of Sweet Biscuit Developed from Quality Protein Maize for Nutritional Security of Rural as well as Urban People. International Journal of Current Microbiology and Applied Sciences 2020;9(4):929-933.

21. Priyanka, Kumarari, Usha, Singh. Effect of processing on nutritional status of food materials for their use as supplementary food for pregnant women. Asian Journal of Dairy and Food Research 2013;(32):152-157.

22. Raghuramulu N, Madhavan NK, Kalyanasundaram S, Madhavan KM, Kalyansundaram S, Nair K et al. A Manual of Laboratory Techniques 2003.

23. Rodriguez-Miranda J, Ruiz-López II, Herman-Lara E, Martínez-Sánchez CE, Delgado- Licon E, VivarVera MA. Development of extruded snacks using taro (Colocassia esculenta) and nixtamalized maize (Zea mays) flour blends. Food Science and Technology 2011;44(3):673-680.

24. Romero HM, Santra D, Rose D, Zhang Y. Dough rheological properties and texture of gluten-free pasta based on proso millet flour. Journal of Cereal Science 2017;74:238-243.

25. Shobha D, Sreeramasetty TA, Gowda KP, Shivakumar GB. Storage influence on the functional, sensory and keeping quality of quality protein maize flour. Journal of Food Science and Technology 2014;51(11): 3154-3162.

26. Shobha D, Vijayalakshmi D, Asha KJ. Evaluation of maize flour incorporated vermicelli for nutritional, sensory and storage quality. Journal of Food Science and Technology 2015;52(11):7173-7181. 
27. Singh Y, Prasad K. Moringa oleifera leaf as functional food powder: Characterization and uses. International Journal of Agriculture and food science technology 2013;4(4):317-324.

28. Speizer FE, Colditz GA, Hunter DJ, Rosner B, Hennekens C. Prospective study of smoking, antioxidant intake, and lung cancer in middle-aged women (USA). Cancer Causes \& Control 1999;10(5):475-482.

29. Tańska M, Konopka I, Ruszkowska M. Sensory, physicochemical and water sorption properties of corn extrudates enriched with spirulina. Plant Foods for Human Nutrition 2017;72(3):250-257.

30. Vasal SK. The quality protein maize story. Food and Nutrition Bulletin 2000;21(4):445-450.

31. Yadav DN, Sharma M, Chikara N, Anand T, Bansal S. Quality characteristics of vegetable-blended wheat-pearl millet composite pasta. Agricultural Research 2014;3(3):263-270. 